\title{
THE IMPORTANCE OF DEVELOPING THE WRITING SKILL IN THE MILITARY
}

\author{
Georgeta OBILIȘTEANU, Brândușa-Oana NICULESCU \\ "Nicolae Bălcescu" Land Forces Academy, Sibiu, Romania \\ pusa_obi@hotmail.com, branducosma@yahoo.com
}

\begin{abstract}
The development of the four language skills has always been hard work for teachers as well as for students, the writing skill being a particularly challenging one. Writing in English for achieving various goals is certainly a major activity of all civilian and military higher education institutions throughout the world. In their daily activities, army leaders convey their intent, ideas, purpose and vision to superior echelons, peers and subordinates in oral or written form. Military officers perform many of their duties by means of intelligible, concise, coherent, and meaningful written messages. The need for writing correctly is an absolutely indispensable skill in itself. Therefore, teachers working in the military system of education should be concerned with developing, improving and practising the writing skill which is an important quality of leadership. Military work is very complex, the military system being based on officers' ability to lead and manage military organizations. The paper focuses on the specific characteristics of military writing and provides some formats, with the respective writing tasks and assignments.
\end{abstract}

Keywords: improving writing skill, military English, military documents, devising tasks and assignments.

\section{Introduction}

Nowadays the writing ability is as important as the speaking skill since the readership to which army leaders address is by far larger than through face-to-face or telephone conversations. The circumstances in which they transmit written messages are specific to the military environment. Whether this is to write an e-mail, plan a memorandum, make a power point presentation, or prepare a report, specific standards have to be obeyed in all these types of writing.

Writing in English is of paramount importance to the military personnel who work in the Romanian Armed Forces. Operating within a multinational formation in an international army setting requires a high level of proficiency in using this productive skill. Cadets and officers who come from non-speaking English countries find the acquisition and strengthening of the skill of military writing to be quite difficult.

When writing a military document, an important aspect that should be taken into consideration is that it is different from a general document in terms of its objectives, content and readership. "The fundamental purpose of scientific discourse is not the mere presentation of information and thought but rather its actual communication. It does not matter how pleased an author might be to have converted all the right data into sentences and paragraphs; it matters only if a large majority of the reading audience accurately perceives what the author had in mind" [1].

2. The importance of English writing for military purpose

When students graduate from their primary 
and secondary education, they have already gone through the traditional general English syllabus and, irrespective of how skilled they have become in using the language, they will need to meet the professional requirements of their future jobs that is to achieve a practical purpose in their English studies. The general knowledge they have acquired is unquestionably an essential prerequisite of becoming a successful military leader. In attending the different service academies, cadets have to possess knowledge of the military as well as to improve the four English language skills, by putting a lot of effort in improving the productive ones, so necessary in communicating in a challenging international environment.

By its nature, the productive skill of writing is more difficult to improve than the productive skill of speaking. As we have noticed during our classes, writing is not the military students' preferred activity. Taking into consideration the characteristics of their professional formation, they are more interested in action than in communicating meaning. Nevertheless, there are various circumstances demanding them to produce and convey written messages. The written forms of communication important for the military personnel in order to communicate ideas and concepts are as follows:

$>$ e-mails - are very important as the wellwritten ones lead to mission accomplishment while the poorlyformatted ones may lead to mission failure [2]. Being so frequently used, the personnel should adopt the military e-mail etiquette and follow some tips: formulate subjects with keywords, be economical and concise enough to avoid scrolling and get to the point up front.

$>$ orders - are critical as they ensure that the receiving personnel understand them properly and that there is no ambiguity in the language that could lead to misunderstandings and confusion. Orders must be written in such a manner as to accurately describe the army leader's intent, details of the specific mission and the clear responsibilities of the receiver [3].

$>$ memoranda - are the main military's format for composing service correspondence. Memos are used mainly by staff officers to communicate some important issues to subordinate staff or to convince the receiver to take actions, give feedback or react to previously discussed documents or issues. Writing them correctly demands shortness and conciseness in formulation and providing the information needed as well as the sources for finding additional details.

$>$ PowerPoint presentations - are "as much a writing skill as any other in today's military" [4]. Well-written PowerPoint presentations should consist of accurate and truthful slides, containing short and succinct bullet points that must be carefully balanced with paragraphs when the circumstances demand it.

military reports - are the most frequent task during STANAG 6001 English exams, hence the military should be familiar with this form of writing. Moreover, they are the most useful form service men will be exposed to in the army. In writing military reports, some points should be kept in mind: present facts in order to be credible, keep paragraphs concise, capitalize all positions and ranks. What must be underlined is that the purpose of military reports is to disseminate information.

letters - are also given as a task within the English exams according to STANAG 6001. They are written for official business with external organizations, member of the public, as well as between some Ministry of Defence (MOD) institutions. When written to a person who is not part of the

MOD, military-network phone numbers 
or military email addresses must not be included.

The importance of developing the writing skill for the military certainly derives from the fact that cadets learn how to meaningfully and coherently communicate by using correct punctuation, spelling, appropriate lexical-grammatical patterns and the format specific to the military etiquette.

\section{Characteristics of military writing}

English language teachers of the Land Forces Academy of Sibiu are primarily concerned with developing and strengthening the skill of writing since in their careers future army leaders will be exposed to most of the above mentioned types of military writing. In addition to that, our cadets have to get familiarized with rules and restrictions that derive from the Army Standard of writing. According to the features presented in Writing and Speaking Skills for Army Leaders, effective military writing "transmits a clear message in a single, rapid reading and is generally free of errors in grammar, mechanics, and usage. Good Army writing is concise, organized, and right to the point" [5].

The principles that military students have to incorporate in order to produce good written communication are: short, sensible sentences and paragraphs (the average sentence consists of up to 15 words and the average paragraph has about lines); efficient phrases, vocabulary, and images (commonly accepted words and pictures, avoiding slang, and acronyms); active voice (primarily used because it implies fewer words, takes less time to read and identifies the doer of the action); packaging that supports (stating that the military put their position, conclusion, or recommendation up front at the beginning and arrange their writing so that readers can easily and fast grasp their intent) [6].

In our opinion, some of the characteristics that any piece of good military writing should display are:

$\checkmark$ clarity - requiring cadets to explain, give examples, and express their messages in a distinct and comprehensible manner that becomes obvious to the reader. In order to add clarity to sentences, students should use short words, delete extraneous words, reduce clauses to phrases, and control sentence length [7].

$\checkmark$ accuracy - referring to the correct use of vocabulary, grammar, spelling and punctuation.

$\checkmark$ simplicity - using simple and plain words and only the relevant details.

$\checkmark$ conciseness - requiring to include only essential information. Messages are rendered in the fewest words consistent with completeness, clearness, and courtesy.

$\checkmark$ coherence - implying placing ideas in an orderly sequence, and combining words that are mutually supporting, giving sense and meaning to the whole message.

$\checkmark$ emphasis - referring to the careful and thoughtful arrangement of words (ideas be treated in the order of their importance).

$\checkmark$ relevance - addressing and helping to resolve the question at issue.

$\checkmark$ completeness - meaning that all necessary information is included. When other sources need to be consulted, the information contained in those references should be summarized so that all questions are suitably answered.

When writing military documents, cadets are required to obey a set of standards and rules which are typical of this type of texts. In applying these norms, they make sure that their communication is accurately transmitted to the readership. This is very important if we consider that in the military context the recipients are supposed to act immediately in accordance with what they have understood.

Given the specific features of the military writing that future officers must acquire, the English language teachers should carefully select the teaching material, 
equipping students with experience [8] that will prove relevant and practically useful when they take part in various missions.

\section{Several tasks and assignments used in the military classroom}

In the context of developing the military writing skill, the foreign language teachers' great responsibility is that of identifying the specific needs of students, which are closely related to the job requirements referring to this skill. In order to do this, teachers will have to pay attention to the teaching materials that they will need to use in class. Then the teachers' main focus is to devise appropriate didactic activities adapted to the language proficiency of the group of students they work with.

The use of authentic materials may enhance the classroom interaction and students' motivation since they are aware of the fact that genuine documents and realistic situations lead to acquiring the necessary experience that will enable them to function adequately in their future jobs. In Likaj Manjola's opinion, "the writing tasks practised in the classroom have to be taken from real life situations and military environment, leaving aside abstract and non-authentic tasks that they may never face in their daily routine" [9].

In the following we suggest several tasks/assignments that have proven successful during our English military writing classes. These exercises are carried out either individually or as pair work/group work activities. It is necessary for cadets to receive feedback both from the teachers and from their colleagues in order to increase the efficacy of these exercises.

For example, useful tasks for developing the e-mail writing skill can be formulated as follows:

You are head of the class and you have to write an info e-mail to your classmates telling them that the meeting with the battalion commander has been postponed for later date. Use less than 100 words. or

You are a $3^{\text {rd }}$ year cadet and want to take part in the ERASMUS+ Programme for young officers. Write an e-mail to the teaching staff of the Gen. Tadeusz Kosciuszko Military Academy of Land Forces, Wroclaw, Poland asking them whether they can be your scientific advisor for the Bachelor's Degree thesis you plan to produce. Use less than 150 words.

In issuing orders, teachers can use the following activities:

You are the platoon commander. Give an order to the head of the infantry class asking him/her to organize the march back from the mountain training camp to the Academy.

or

You are at the firing range. Issue an order to one of the comrades in your platoon to show how to fire a round with his/her individual weapon (IW).

In order to make the writing of memoranda a more entertaining activity in class, cadets can be asked to deal with the following writing requirements:

Write a memo to inform the cadets about a Cultural Awareness course. Include the following: list of participants to be received by 03 March: 2nd year cadets belonging to the Military Leadership program of study; place: Armed Forces Academy of General Milan Rastislav Štefánik,, Liptovský Mikuláš, Slovak Republic; date and time; purpose: lectures, debates and group discussions, evaluation.

or

As the Coordinator of the judo team in the Academy, you have been asked to organise a mandatory training schedule for all participants selected for Spartachiada competition. You have decided to delegate this job to another member of your staff. Write him a memorandum giving him specific instructions about the content of the training, the exact number of cadets, how the training is to be structured, where the training must take place and the proposed dates. Include any other information you think will be necessary for 
him to do the task without the need to refer back to you.

Although PowerPoint seems to be related to the speaking skill, it is as much a writing skill as any other in today's military. Therefore, possible tasks for developing the ability of producing the right slides can be designed as follows:

Prepare a PowerPoint presentation of the Land Forces Academy for your counterparts coming within the Cultural Understanding and Language Proficiency program.

or

Make a PowerPoint presentation of all the curricular and extracurricular activities taking place in the Land Forces Academy in order to motivate young people to attend the courses of the academy.

Military reports have to be written in accordance with STANAG 6001 standards. The military students can be assigned one of the following tasks:

You are taking part in a NATO mission and your Commanding Officer (CO) has asked you to organize a humanitarian event to raise money for building a local hospital. Write a report to your CO in which you present your ideas - what you plan to do, when and where. You can choose one of the following ideas for the action or think of something different: Army band concert; marathon; a soccer/basketball...match; Bingo game, etc.

or

You have returned from a patrol mission during which your crew was attacked by a group of armed civilians. Write a report to your commanding officer referring to: the incident, description of a crew member who impressed you and the measures to be taken due to the incident.

Teachers should also take into account the fact that cadets will need to write both informal and formal letters. So, the activities have to be focused on the differences between the formal and informal register of English. These tasks can be fruitfully exploited in the classroom for developing the skill of writing letters: Write a letter of application for the position of military instructor at the Military Training Centre. The successful candidate must: have at least 5 years of experience; have specialized training; speak English; have leader abilities.

or

You are currently attending a military course abroad. You are dissatisfied with the accommodation and services provided. Write a letter of complaint to the military hostel administrator, explaining the situation and the remedial measures you expect to be taken.

In covering the above mentioned tasks and assignments, we did not consider the cadets to be passive receivers of the transmitted knowledge; on the contrary they played an active role in clearly and concisely communicating through writing.

\section{Conclusions}

The job requirements demand teachers be aware that their work is not confined only to correcting the language mistakes students make during classes or explaining to them the writing standards, norms, rules, techniques. Teachers are responsible for creating optimum conditions for learning. In fact, this is the new role that teachers should assume, i.e. that of foreign language acquisition facilitators.

Learners should be given tasks that are intellectually demanding and relevant for their future jobs, especially when writing. When these are not challenging enough, adults feel frustrated and demotivated and no longer actively take part in the didactic activities designed by the teacher. 


\section{References}

[1] Gopen, George D., Swan, Judith A., The Science of Scientific Writing, in American Scientist, Journal of Sigma Xi, p. 1, November-December 1990, retrieved from http://www.americanscientist.org/issues/pub/the-science-of-scientific-writing/1, 10 February 2017.

[2] Sehgal, Kabir, How to Write Email with Military Precision, posted on November 22, 2016, retrieved from https://hbr.org/2016/11/how-to-write-email-with-military-precision, 10 February 2017.

[3] Lemar, Alexander F., The Military and Writing: It's Complicated, in The Military Writers Guild, posted on November 10, 2015, retrieved from https://www.militarywritersguild.org/military-writing-complicated/, 10 February 2017.

[4] Sukman, Dan, and Finney, Nate, Military Writing Takes Many Forms, in Modern War Institute at West Point, posted on September 7, 2016, retrieved from http://mwi.usma.edu/military-writing-takes-many-forms/, 10 February 2017.

[5] Command and General Staff School, U.S. Army Command and General Staff College (CGSC) 22-2, Writing and Speaking Skills for Army Leaders. Student text, Fort Leavenworth, Kansas, 2009, p.1-1.

[6] Ibidem, pp.1-2 - 1-3.

[7] Bekno, John, Action Officer. Staff Writing, Fort Monroe, Virginia, U.S. Army Training and Doctrine Command, p.11-12, retrieved from http://www.dtic.mil/whs/directives/plainlanguage/ActionOfficer_StaffWriting.pdf, 12 February 2017.

[8] Rus, Dana, Developing Technical Writing Skills to Engineering Students, in Procedia Technology, vol. 19, 2015, pp. 1109-1114, retrieved from http://www.sciencedirect.com/science/article/pii/S2212017315001590, 12 February 2017.

[9] Manjola, Likaj, Teaching Writing through Communicative Approach in Military English, in Journal of Education and Practice, Vol. 6, No. 20, pp. 102-107, 2015. 